\title{
The effect of buffer solution choice on protein adsorption and lubrication
}

\section{Maria Parkes, Connor Myant, Philippa M. Cann and Janet S.S. Wong*}

Tribology Group, Department of Mechanical Engineering, Imperial College London, SW7 2AZ London, UK

*corresponding author

\section{Submission Abstract (max 120 words)}

In vitro buffers are frequently used to formulate model synovial fluids to investigate the role of individual constituents in synovial joint lubrication. This work examines how buffer choice affects protein film formation in static and rolling conditions. Solution $\mathrm{pH}$ dominates both the protein adsorption kinetics and the formation of tribofilms in static and rolling conditions respectively. Under static conditions, equilibrium adsorbed protein films from all buffers tested have similar properties although three distinct modes of adsorption, governed by the $\mathrm{pH}$ of the buffer, are observed. Films formed under rolling conditions are also $\mathrm{pH}$ dependent, with large irregular deposits formed in solutions with $\mathrm{pH} 7.4$ or lower, The adsorption properties of proteins under static conditions only partially govern the lubrication properties of proteins.

\begin{abstract}
Synovial fluid contains proteins which can participate in surface film formation and the lubrication of artificial joints. In laboratory experiments, model synovial fluids with a range of buffers are frequently used by various investigators. Buffer compositions with different $\mathrm{pH}$, ionic strength and buffer chemistry may affect protein adsorption, and hence film formation. To clarify the role of buffers in protein film formations, the static adsorption of BSA in a selection of buffers is studied using a quartz crystal microbalance. Three distinct modes of adsorption are observed, but on reaching equilibrium, the adsorbed BSA layers have similar viscoelastic properties in all buffer solutions. The static adsorption results are compared with lubricants film formed in model rolling contacts. Films formed under rolling conditions are $\mathrm{pH}$ dependent. Thin, uniform films consistent with adsorbed films, and nonuniform films, with large irregular deposits are formed in high and low pH solutions respectively. The results show that the $\mathrm{pH}$ of the solution dominates both the adsorption kinetics of proteins under static conditions and the formation of tribofilms in rolling conditions. However, the adsorption properties of proteins under static conditions only partially govern the lubrication property of protein solutions.
\end{abstract}

Keywords: Artificial hip joints, Boundary lubrication, Synovial fluid, Protein adsorption 


\section{Introduction}

Synovial fluid (SF), is a complex aqueous suspension, which contains numerous proteins, proteoglycans, lipids and Hyaluronic acid. The exact composition varies from patient to patient, making a 'master' solution hard to define. For healthy $\mathrm{SF}$ the $\mathrm{pH}$ ranges from between 7.3-7.4 and the total protein content is $18-20 \mathrm{mg} \mathrm{ml}^{-1}[1]$. In the diseased state the $\mathrm{pH}$ and protein concentration can increase up to 8.4 [2] and $34 \mathrm{mg} \mathrm{ml}^{-1}$ respectively [1]. It is very difficult to collect and store adequate volumes of SF required to perform tribological investigations. Hence, model SF lubricants are employed. Bovine Calf Serum (BCS) is commonly used as a test lubricant [3] as it is readily available, has similar $\mathrm{pH}$ and salt levels to SF, and can be diluted to achieve a similar overall protein concentration as SF. Despite this, BCS has been shown to not closely simulate the lubrication of SF in either friction or wear studies $[1,3,4]$. Further disadvantages of BCS are the variation from batch to batch in its constituents, and the different protein composition to synovial fluid. Another approach is to prepare model fluids using a known concentration of a SF component in a buffer. This allows the roles of individual SF components to be studied in a systematic manner. It also presents the possibility of preparing model fluids which more closely match the variation in fluids from patient to patient.

Proteins, as the main constituent of both SF and BCS, are commonly considered as molecules that may improve joint lubrication. Protein solutions have been shown to reduce friction and wear in several studies [5-8], commonly attributed to an 'adsorbed' protein film. Buffers are used when preparing protein solutions to control the $\mathrm{pH}$ and ionic strength of the solution. The choice of buffer is at the discretion of the investigator, and a range of buffers are used by different laboratories. However, the effect of the buffer composition on protein film formation is generally not acknowledged. Protein adsorption is a complicated phenomenon, influenced by many factors, such as solution $\mathrm{pH}[9,10]$, ionic concentration [11] , protein concentration [12], hydrophobic interactions [13] and protein conformation [7]. As buffers vary in chemistry, $\mathrm{pH}$ and ionic strength, the choice of buffer will impact on the protein adsorption to test surfaces, including the rate of adsorption, total adsorbed amounts, reversibility of adsorption, and the properties of an adsorbed layer. This calls into question the validity of comparing adsorbed protein films in tests using different buffers, where the effects of buffer composition cannot be distinguished from other factors. The role of buffers on protein adsorption requires clarification.

In this work a distinction will be made between adsorbed and deposited layers. Adsorbed layers are proteins layers formed on a surface whose nature is similar to those formed under equilibrium conditions in a static solution. These layers are composed of proteins and hydrated ions only. Deposited layers are observed on a surface following dynamic testing. Due to the tribological conditions, these deposited layers can have very different chemical and physical properties to those adsorbed films formed using the same lubricant. There is no consensus on the existence, nature, and the effects of the protein films deposited on joint lubrication. Deposited protein films have been described as 'solid-like' layers, gels or 
viscous surface layers. 'Solid-like' layers strongly adhere to the surface and are highly immobile. This type of layer has been associated with a reduction in metal-on-metal wear $[3,8]$. One should note that these solid like layers have only been observed ex-situ when the layers have been dried. As protein layers have been observed to alter in strength and surface adherence dependent on hydration $[7,14,15]$, the properties of dried surface layers should only be tentatively linked to in-situ layers.

Gel layers differ from 'solid-like' layers as they are highly hydrated, but they still adhere strongly to rubbing surfaces $[7,8,16]$. Denatured albumin which is less hydrated than native albumin has been shown to preferentially adsorb on hydrophobic surfaces $[7,12,17]$. Widmer et al. [14] and Heuberger et al. [7] surmise that adsorbed, hydrated protein gel films give lower friction coefficients than more solid-like films composed of compact, heatdenatured, unfolded albumin based on their work with UHMWPE and denatured proteins. In work on artificial cartilage, Murakami et al. [18] have directly observed that adsorbed protein gel layers in a contact are resistant to sliding and reduce friction. However, the contact pressures exerted by artificial cartilage are much lower than that from artificial joints, and the material properties, in particular the structure and the hydration of artificial cartilage is quite different to implant materials. Gel surface layers were observed by Myant et al. with a point contact between a femoral head and a glass disc as shown in [11]. A protein enriched film was formed at the inlet and was carried through the contact. These films were thicker than statically adsorbed films reaching thicknesses greater than $100 \mathrm{~nm}$. The films were easily disrupted by reversal in flow direction and removed by surface scratches. This suggests weak surface adhesion, particularly when compared to dried deposits. However, once damaged or removed these films rapidly recovered to $>100 \mathrm{~nm}$ within a few seconds.

This lack of consensus across the field on the nature of protein film lubrication may be due to the complex behaviour of proteins, which in turn can be dependent on how the protein solutions are prepared and the buffer used. The adsorption of proteins on surfaces is frequently investigated under a static, equilibrated condition, which can be very different to the conditions in a tribological contact. It is unknown whether the behaviour of protein adsorption observed under static conditions can be used to predict wear rates and friction of rubbing surfaces immersed in protein solutions during dynamic processes. Mechanisms other than protein surface adsorption may be more significant in governing the success of protein in facilitating joint lubrication. In this work the role of model synovial fluid buffers in protein lubrication is investigated. In particular, we examine which aspect of these buffers $(\mathrm{pH}$, ionic strength or buffer molecule) has the dominant effect in protein surface adsorption. Tribological tests are then used to determine the role of protein surface adsorption in film formation under rolling conditions.

Two key questions were asked: 
1. What is the effect of buffer composition on protein adsorption and EHL film formation?

2. Are static adsorption measurements relevant to the lubrication process?

Albumin was chosen as it is the predominant protein in synovial fluid. The static adsorption $[19,20]$ and tribological characteristics $[7,21-23]$ of albumin have been widely studied, but no work to date examines the relationship between these behaviours and the impact of buffer choice. In this study the adsorption properties of different albumin/buffer solutions were measured using a quartz crystal microbalance (QCM). The results were compared to film formation under rolling lubrication conditions for a ball-on-flat contact. Whilst this is not a direct simulation of an artificial joint, the test conditions are chosen to be close to those experienced in a metal on metal (CoCrMo) hip prosthesis. The test speed is $10 \mathrm{~mm} \mathrm{~s}^{-1}$, which is in the normal operating range for the hip joint [24]. The mean contact pressure used in this study is $200 \mathrm{MPa}$, which is higher than that experienced by correctly operating joints (< $100 \mathrm{MPa}$ [21]). However, pressures in this range do occur in small diameter hip joints with large clearance [21], or under edge loading [25].

\section{Materials and Methods}

The adsorption properties of Bovine Serum Albumin (BSA) under static condition in a selection of model synovial fluid buffers are investigated with QCM. The effect of buffer composition on lubricant film thickness formed under continuous rolling was then examined by optical interferometry for a glass/CoCrMo interface.

\subsection{Solutions}

Eight buffer solutions are prepared as listed in table 1, all of which have been used in published work on protein lubrication in synovial joints [4,22,26-28]. Di-ionised water, with $\mathrm{pH} \sim 5.6$, is used as the simplest buffer, with no adjustments to $\mathrm{pH}$ or additional salt. To test the effect of ionic strength, buffers are prepared at an ionic strength of $\leq 10 \mathrm{mM}$ or physiological ionic strength of $154 \mathrm{mM}$. The $\mathrm{pH}$ of the buffers is also varied to investigate the effect of $\mathrm{pH}$ on protein buffers lubrication, with water and saline used with no $\mathrm{pH}$ adjustment ( $\mathrm{pH} \sim 5.6$ ), and other buffers having either $\mathrm{pH} 7.4$ representing healthy synovial fluid, or 8.1 representing osteoarthritic diseased fluid. Viscosities are measured for freshly prepared buffer solutions using a concentric cylinder geometry on a DHR Rheometer (TA Instruments) at $25{ }^{\circ} \mathrm{C}$ and at a shear rate of $10 \mathrm{~s}^{-1}$. A Zetasizer Nano (Malvern Instruments) is used to measure the diffusion coefficient, hence the hydrodynamic radius of BSA at a concentration of $10 \mathrm{mg} \mathrm{ml}^{-1}$ in each buffer.

All buffers used in this work are aqueous solutions of the follow salts: sodium chloride salt of analytical grade ( $\mathrm{NaCl})$ (VWR, 27810), 2-amino-2-(hydroxymethyl)-1,3-propanediol (Tris) (SigmaAldrich, T-87602), Phosphate Buffered Saline (PBS) (Sigma Aldrich, P5368), and 4-(2Hydroxyethyl)piperazine-1-ethanesulfonic acid (HEPES) (Sigma Aldrich, 54457). All di- 
ionised water used is ultrapure Milli-Q water (resistance $>18 \mathrm{M} \Omega \mathrm{cm}$ ). Buffers are prepared, and their $\mathrm{pH}$ adjusted using sodium hydroxide ( $\mathrm{NaOH})(\mathrm{VWR}, 28244.262)$ or hydrogen chloride ( $\mathrm{HCl}$ ) (VWR, 20252.335) as necessary. They are used immediately, or stored at $5{ }^{\circ} \mathrm{C}$ and used within one month. Bovine serum albumin, (Sigma Aldrich, A7906, $\geq 98 \%$ agarose gel electrophoresis, lyophilized powder), is used without further purification. All solutions are prepared with a concentration of $10 \mathrm{mg} \mathrm{ml}^{-1}$ BSA, which is within the physiological range for albumin in healthy synovial fluid [1]. To avoid confusion, buffers in this work mean buffers with no protein added. Solutions with proteins added to buffers are referred to as protein solutions.

\subsection{Adsorption measurements with quartz crystal microbalance}

Protein adsorption dynamics and the nature of the adsorbed film were examined with a quartz crystal microbalance (QCM). In a QCM experiment, proteins are allowed to adsorb on a piece of quartz crystal which was originally oscillating at its resonant frequency. The adsorption of protein changes the resonant frequency (frequency shift, $\Delta f$,) and the motional resistance of the crystal. Simultaneous measurements of the frequency shift and change in resistance, $\Delta R$, provide insight into the mechanical properties of the adsorbed layer. The adsorbed mass can be determined by accounting for the viscous loading using the change in resistance.

\subsubsection{QCM theory}

QCM uses the change in resonant frequency, $\Delta f$, of an oscillating quartz crystal to monitor the change in mass and viscous loading of the crystal due to adsorbed molecules. When the adsorbed molecules form a uniform, rigid layer, with no viscous loading the Sauerbery equation relates the change in frequency due to mass, $\Delta f_{\text {mass }}$ and the adsorbed mass per unit area $(M)[29]$ :

$$
M=-\frac{C}{n} \Delta f_{\text {mass }}
$$

where $\mathrm{C}$ (= $17.7 \mathrm{ng} \mathrm{Hz}^{-1} \mathrm{~cm}^{-2}$ for a $5 \mathrm{MHz}$ AT-cut quartz crystal at room temperature) is the sensitivity factor, and $n$ is the overtone number.

When operating in a liquid, the crystal will experience a further frequency shift related to the density, $\rho_{l}$; and viscosity, $\eta_{l}$, of the liquid. This was examined by Kanazawa and Gordon [30], and the relationship is:

$$
\Delta f_{\text {viscous }}=f_{u}^{3 / 2}\left(\frac{\rho_{l} \eta_{l}}{\pi \rho_{q} \mu_{q}}\right)^{1 / 2}
$$


where $f_{u}$ is the frequency of oscillation of clean, unloaded crystal in a vacuum, and $\rho_{q}$ and $\mu_{q}$ are the density and shear modulus of quartz respectively.

In the case where there is both mass and viscous loading the total measured frequency shift, $\Delta f$ is a linear combination of the frequency shift due to the mass loading, $\Delta f_{\text {mass }}$ and the viscous loading $\Delta f_{\text {viscous }}[31,32]$ such that:

$$
\Delta f=\Delta f_{\text {mass }}+\Delta f_{\text {viscous }}
$$

Adsorbed protein films are known to contain water and ions. As a consequence, a protein film is not necessarily a rigid film as assumed by equation (1) and can demonstrate significant viscoelasticity [33]. The frequency shift due to energy dissipation in the protein film and the frequency shift due to adsorbed mass cannot be separated if only $\Delta f$ is measured [31]. In our system we monitor $\Delta R$ to separate the mass and dissipation effects. An alternative approach is the use of QCM in disspative mode (QCM-D) or impedance analysis [34,35].

The change in resistance, $\Delta R$ is dependent on the viscous loading of the crystal and not the mass loading [32] such that:

$$
\Delta R=K_{1}\left(\rho_{l} \eta_{l}\right)^{1 / 2}
$$

and

$$
\Delta f_{\text {viscous }}=K_{2} \Delta R
$$

where $K_{1}$ and $K_{2}$ are constants dependent on the quartz crystal properties. The value of $K_{2}$ for a $5 \mathrm{MHz}$ crystal is $-2 \mathrm{~Hz} \Omega^{-1}$ [32]. This allows a real-time correction for the viscous loading to be made [32] so that the change in frequency due to mass alone can be calculated as:

$$
\Delta f_{\text {mass }}=\Delta f-K_{2} \Delta R
$$

The absolute value of the ratio $\Delta R / \Delta f$ can also be used to indicate the relative importance of adsorbed mass over viscosity effects, with a smaller ratio indicating a dominance of the elastic mass effect [36].

\subsubsection{Protein Adsorption under static condition}

A quartz crystal microbalance (SRS, QCM200) is used to follow the adsorption of BSA on Silica $\left(\mathrm{SiO}_{2}\right)$ coated quartz crystals. Silica crystals are chosen to match the surface of the disc specimen used for the lubricant film thickness measurements. It should be noted that the adsorption results are dependent on the interaction of the protein with the substrate, and the results on silica may differ from those on implant surfaces. Furthermore, changes in adsorption due to processes such as corrosion that may be relevant for materials like CoCrMo are not captured here. Quartz crystals are mounted in a liquid flow cell, with flow controlled at $60 \mu \mathrm{min}^{-1}$. The test setup is shown in figure 1. The variations of frequency 
$(\Delta f)$ and resistance $(\Delta R)$ of the crystal are monitored as a function of time, during the sequential addition of buffer (baseline), BSA solution (protein solution), and buffer again (rinsing), to the liquid flow cell. All of the buffers listed in Table 1 are used for QCM measurements with a BSA concentration of $10 \mathrm{mg} \mathrm{ml}^{-1}$. Measurements are taken at room temperature $\left(20^{\circ} \mathrm{C}\right)$.

The crystals and the flow cell are cleaned separately prior to each experiment, by soaking and rinsing with $2 \%$ detergent solution, followed by rinsing with copious amounts of Milli-Q water, and then isopropanol; followed by drying with nitrogen. Crystals are then treated for 10 minutes in air plasma just before use.

\subsection{Film thickness measurements in a rolling contact}

A ball-on-flat device (Ultra Thin Film EHL PCS instruments UK) utilising thin film optical interferometry, as shown in figure 2 , is used to measure film thickness of protein solutions in a rolling contact. The technique has been extensively used to measure lubricant film thickness for base fluids and additive solutions. More details are provided in [26]. The test configuration uses a $19.8 \mathrm{~mm}$ diameter ball loaded against a glass disc. The underside of the disc in contact with the ball is chromium coated (10 $\mathrm{nm}$ thick) overlaid by a thicker silica layer (500 $\mathrm{nm}$ thick). This combination of coatings is necessary to generate the reflective conditions needed for the interferometry measurements. The normal load, speed and relative amounts of rolling and sliding applied to the tribological contact are specified by the user.

The ball and disc are driven independently so that a range of slide-roll conditions can be studied from $0 \%$ (pure rolling) to $200 \%$ (ball stationary pure sliding). In the current work the film thickness measurements were made under nominal pure rolling. This condition is not representative of motion in hip joints which is pure sliding, however the objective of the tests was to compare protein film formation for static (unloaded) surfaces and in a tribological contact where loading and motion are present. In sliding contacts wear inevitably occurs and is difficult to measure thin films on damaged surfaces. In addition the authors have previously published a number of papers studying film formation under sliding conditions $[21,24,37,38]$. In this study therefore wear was avoided by using a rolling contact. However the surface films and lubricating fluid still experience shear stresses.

An initial film thickness reading at a normal load of $5 \mathrm{~N}$ is taken immediately after filling the lubricant bath with BSA solution and used as the zero thickness measurement. With normal loading removed and fluid separating the two surfaces, proteins are allowed to adsorb to the two test surfaces from the solution for 20 minutes in static condition. The contact is then loaded to $5 \mathrm{~N}$, corresponding to a mean contact pressure of $200 \mathrm{MPa}$ and film thickness is again measured. In some tests film formation was also measured after 5, 10, 15 and 20 minutes by briefly loading the ball. 
Film thickness as a function of time during rubbing was monitored with the ball and disc rotated at $10 \mathrm{~mm} \mathrm{~s}^{-1}$ to achieve a nominal pure rolling condition. Test duration was 20 minutes after which the residual film in a static loaded contact was measured.

At the end of the test a CCD camera was mounted on the microscope (replacing the spectrometer) and images taken from the contact zone during rolling. This provided further information on the protein lubrication mechanisms.

The test solutions and test conditions are summarised in Table 3. In the light of the QCM results reported in Section 3.1 only a limited range of solution were tested in the EHL device. These had the same ionic strength $(154 \mathrm{mM})$ but different pHs $(5.6,7.4,8.1)$.

\section{Results}

\subsection{The effect of different buffers on protein adsorption under static condition}

For all solutions, a minimum of three independent measurements are taken and averaged. The change in frequency due to mass $\left(\Delta f_{\text {mass }}\right)$ as calculated using Eqn. (6) and the simultaneous change in resistance $(\Delta R)$ with time are shown in figure 3 . All protein solutions result in an initial rapid change in both frequency and resistance as the solutions enter the flow cell. The rates of frequency and resistance change eventually slow, and both $\Delta f_{\text {mass }}$ and $\Delta R$ reach plateau values. On rinsing with buffers, a decrease in $\Delta R$ is observed in all buffers due to the change in viscous loading between the more viscous protein solution and the less viscous buffer solution. The $\Delta f_{\text {mass }}$ remains constant showing there is negligible desorption of proteins on rinsing. The permanent frequency shift from the baseline frequency observed after rinsing indicates an adsorbed protein layer remains at the crystal surface.

$\Delta R / \Delta f$ is plotted against $\Delta f$ (figure 4) for the initial phase of the adsorption test (up to 800 seconds) after which the frequency and resistance change began to stabilise. As discussed in section 2.2.1 the ratio $\Delta R / \Delta f$ provides an insight into the mechanical properties of the adsorbed layer. Hence figure 4 indicates how the viscoelastic property of the adsorbed film changes as the adsorption process progresses (i.e. as $-\Delta f$ increases). Three types of adsorption behaviour are observed. In the case of water and saline $\mathrm{pH} 5.6$ protein solutions, there is a transition from an elastic response ( $\Delta R / \Delta f$ close to zero) to a viscoelastic response at around $\Delta f=30 \mathrm{~Hz}$. This suggests that the adsorbed layers are relatively rigid initially. Further adsorption of proteins, possibility with hydrated salts and water, however, induces viscous behaviour of the film. In the case of Saline pH 7.4, PBS, HEPES, TRIS and TRIS saline $\mathrm{pH} 7.4$ protein solutions, $\Delta R / \Delta f$ quickly rises and reaches a plateau with increasing $-\Delta f$. These films are viscoelastic throughout their formation. TRIS saline PH 8.1 results in adsorbed films that are highly viscous initially, but reduces in viscous nature as adsorption progresses. 
The final $\Delta R$ and $\Delta f$ after rinsing for all protein solutions are summarised in table 4 . The final value of $\Delta R / \Delta f$ for all the adsorbed layers is significantly greater than zero, showing all adsorbed layers have some viscoelasticity. The final amount of protein is calculated by converting $\Delta f_{\text {mass }}$ using the Sauerbery equation (1). For all protein solutions the adsorbed mass falls between 600 and $800 \mathrm{ng} \mathrm{cm}^{-2}$. This is between the reported ranges for a protein monolayer (390 and $\left.910 \mathrm{ng} \mathrm{cm}^{-2}[9,19,39,40]\right)$, with a corresponding monolayer thickness of $6.9 \mathrm{~nm}[8]$.

Whilst the final amount of adsorbed protein is similar in all buffers, the rate of protein adsorption is different. The maximum rate of change of $\Delta f_{\text {mass }}$ is taken as the rate of adsorption. This is then plotted as a function of the ionic strength, $\mathrm{pH}$ and buffer chemistry in figure 5. The rate of adsorption is shown to decrease with increasing ionic strength as shown in figure $5 \mathrm{a}$. For $\mathrm{NaCl}$ protein solutions, the effect of ionic strength on the rate of adsorption is most prominent when the ionic strength is increased from 0 to $10 \mathrm{mM}$. Further increase in ionic strength to $154 \mathrm{mM}$ has minimal effect on the rate of protein adsoprtion. Ionic strength insensitivity is also observed with Tris-based buffers, with Tris (5 $\mathrm{mM}$ ) and Tris Saline (154 $\mathrm{mM}$ ) resulting in similar protein adsorption rates. The data falls into two groups suggests that either buffer chemistry and/or buffer $\mathrm{pH}$ are governing protein adsorption process. Figures $5 b$ and $5 c$ clarify the relative importance of buffer chemistry and buffer $\mathrm{pH}$. With increasing $\mathrm{pH}$ the rate of adsorption decreases (figure $5 \mathrm{~b}$ ). Changing the buffer chemistry (figure $5 c$ ) however has a very small effect on the rate of adsorption with differences in the rate being within experimental error.

\subsection{The effect of buffers on film thickness measurements under rolling conditions}

In contact film thickness for each protein solution, as recorded after (1) initial static adsorption and normal load applied; (2) 20 minutes of entrainment in rolling conditions; and then (3) subsequent unloading and reloading, are shown in figure 6. The film thickness after initial adsorption (before rolling) has a maximum of $3.1 \mathrm{~nm}$ for all protein solutions when 5 $\mathrm{N}$ of normal load was applied. This is lower than the estimated thickness of $6.9 \mathrm{~nm}$ from the QCM measurements under static adsorption.

During entrainment the film thickness was measured every minute, as shown in figure 7. Two types of behaviour were observed. For Tris Saline $\mathrm{pH} 8.1$ (figure 7d) a thin film of around $8 \mathrm{~nm}$ was measured at the beginning of the test. This film showed only small variations in thickness, with a slow reduction over the 20 minute period to the final thickness of $3 \mathrm{~nm}$. For the other protein solutions (figures $7 \mathrm{a}, 7 \mathrm{~b}$ and $7 \mathrm{c}$ ) the measured film thickness fluctuated over time, between a maximum of $45 \mathrm{~nm}$ and a minimum of $5 \mathrm{~nm}$. After 20 minutes of rolling, the average film thickness was calculated as the mean of the last 3 measurements in each test. The film thickness obtained for Saline pH 5.8, Saline pH 7.4, Tris Saline pH 7.4 and TRIS saline pH 8.1 protein solutions respectively are 17, 9, 11 and 3 $\mathrm{nm}$ (figure 6). 
The measured film thickness during rolling may be due to the formation of a deposited layer, or an increase in fluid viscosity. The apparent increase in viscosity may be caused by protein enrichment of the lubricant local to the contact [38]. To verify the cause, the contact was unloaded after sliding stopped and reloaded to squeeze out any fluid film. The

thickness of the residual film is given in figure 6 where it can be seen that the residual film is less than the final rolling film for all test solutions.

After the test images were taken of the rolling contact whilst still lubricated. These images (figure 8) show deposits adhered to the ball passing through the contact for solutions at $\mathrm{pH}$ 7.4. For the Tris Saline $\mathrm{pH} 8.1$ protein solution a uniform film with no deposits was observed. The surfaces were then separated and the ball was lightly rinsed with water, dried and then observed under a microscope, as shown in figure 9. These images (figure 9) also show large deposits for solutions with pH 7.4 and lower, but sparse, thin deposits for the Tris Saline $\mathrm{pH} 8.1$ protein solution.

\section{Discussion}

\subsection{Buffer effects on static protein adsorption}

\subsubsection{Ionic strength effect}

Comparing buffers with the same $\mathrm{pH}$ and buffer chemistry we find no change in the viscoelastic properties of the equilibrated adsorbed protein film (figure 4), but some change in the rate of adsorption as shown in figure 5(a). Water $(\mathrm{pH}=5.6)$, with the lower ionic strength has a higher rate of adsorption than, $10 \mathrm{mM}$ and $154 \mathrm{mM}$ saline $\mathrm{pH} 5.8$ solution. This is explained by faster diffusion of the BSA molecules in the water protein solution as measured by DLS (Table 2).

The lower viscosity in water protein solution as compared to saline $\mathrm{pH} 5.8$ protein solution is a result of the change in charge screening between protein molecules in different buffers. In all buffers, the protein is negatively charged and the average distance between protein molecules is $13 \mathrm{~nm}$ (calculated Wigner-Seitz radius for BSA solutions of $10 \mathrm{mg} \mathrm{ml}^{-1}$ ). The Debye screening length in water is $961 \mathrm{~nm}$ compared with $0.78 \mathrm{~nm}$ for saline $\mathrm{pH}$ 5.8. As the Debye screening length in water is much larger than the average distance between protein molecules, the repulsion between negatively charged protein molecules is not screened, resulting in a reduced viscosity [41]. The same trend is seen for Tris (5 $\mathrm{mM})$ and Tris Saline (154 mM), but as the difference in Debye screening lengths is much less, being $4.3 \mathrm{~nm}$ and $0.78 \mathrm{~nm}$ respectively, the effect on diffusion rate is also reduced.

\subsection{2. $\mathrm{pH}$ effect}

The $\mathrm{pH}$ of the protein solution had both an effect on the process of adsorption and the rate of adsorption. By comparing results from saline at $\mathrm{pH} 5.8$ and saline at $\mathrm{pH} 7.4$ as shown in figure $5 b$, we can separate the $\mathrm{pH}$ effect from that of ionic strength. 
The saline $\mathrm{pH} 5.8$ protein solution exhibits a two stage adsorption process (figure 4). A rigid layer is initially formed, indicated by a close to zero $\Delta R / \Delta f$. As protein adsorption continues, the adsorbed layer gradually becomes more viscous and the $\Delta R / \Delta f$ increases to 0.14 . Similar 2-stage adsorption process is also observed for water protein solution ( $\mathrm{pH} 5.6)$. This change from rigid to viscoelastic films has also been seen for albumin adsorbed on hydrophobic surfaces, attributed to a critical surface coverage being reached [15,42]. At this critical coverage, albumin may undergo a structural rearrangement to allow more albumin to adsorb $[9,42]$ or further albumin may adsorb with a more hydrated conformation, closer to the native protein structure [15]. For the saline $\mathrm{pH} 7.4$ protein solution (and the other protein solutions with $\mathrm{pH}$ at 7.4) the adsorption is a one stage process; the adsorbed film is viscoelastic throughout its formation. For Tris saline $\mathrm{pH} \mathrm{8.1,} \mathrm{the} \mathrm{adsorbed} \mathrm{films} \mathrm{are} \mathrm{also}$ always viscoelastic although the viscoelasticity decreases as more proteins are adsorbed.

BSA is known to change conformation with $\mathrm{pH}$, but within the $\mathrm{pH}$ range of these experiments should adopt an $\mathrm{N}$-conformation [43] and no change in conformation of albumin in bulk solutions was observed with Raman spectroscopy (not shown). This leaves the effect of $\mathrm{pH}$ on the electrostatic charge of the protein and silica in various buffers as the cause of differences in adsorption behaviour among these buffers.

It is known that in this $\mathrm{pH}$ range, the amount of negative charges carried by albumin is expected to increase, from -8 at $\mathrm{pH} 5.8$ to -18 at $\mathrm{pH} 7.4$ and -21 at $\mathrm{pH} 8.1$ [43]. Silica is known to be hydrophilic, with a negative charge dependent on both $\mathrm{pH}$ and ionic strength of the surrounding solution. For the buffers used, the charge on silica is between $-0.20 \mathrm{mC}$ $\mathrm{m}^{-2}$ and $-0.50 \mathrm{mC} \mathrm{m}{ }^{-2}$ in the following order of increasing negative charge: Saline $\mathrm{pH} 5.8<$ Saline $\mathrm{pH}$ 7.4/TRIS Saline < TRIS Saline $\mathrm{pH} 8.1$ [44].

At the lowest $\mathrm{pH}$ where the charge carried by the protein and surface are lowest, the repulsion between the protein and surface is relatively easily overcome allowing strong adsorption of a rigid protein layer. With increasing $\mathrm{pH}$, the repulsion between the protein and surface increases; this acts to reduce the rate of protein adsorption, and results in a more hydrated [15], and potentially more loosely bounded viscoelastic layer. The amount of hydrated ions surrounding the protein and incorporated the adsorbed film in the TRIS saline $\mathrm{pH} 8.1$ can be higher than those in the rest of the $\mathrm{pH} 7.4$ protein solutions, resulting in a different relaxation process of the adsorbed film.

The $\mathrm{pH}$ dependence on initial protein adsorption rate reflects a change in adsorption process and the nature of the initial adsorbed films: with low $\mathrm{pH}(\mathrm{pH} 5.8)$ giving more rigid initial films and highest rate, to intermediate $\mathrm{pH}(\mathrm{pH}=7.4)$, then to high $\mathrm{pH}(\mathrm{pH}=8.1)$ resulting in increasingly more viscoelastic films with reducing initial adsorption rate. Although the changes in the rate of adsorption are more pronounced at low ionic strength, the more dramatic change in adsorption behaviour between protein solutions arises from the $\mathrm{pH}$ change. This suggests the role of ionic strength is of secondary importance during 
the film formation process in physiological conditions where the ionic strength of protein solutions is high.

\subsubsection{Buffer Chemistry effects}

The effect of buffer chemistry on protein adsorption can be seen by comparing the results obtained with Saline pH 7.4, PBS, TRIS saline and HEPES saline proteins solutions, as shown in figure $5 \mathrm{c}$. These protein solutions have the same $\mathrm{pH}$ and ionic strength and only differ in the buffer chemistry. The rate of protein adsorption, as well as the viscoelastic properties of adsorbed layers for all buffer chemistries is similar, the slight differences being within experimental error.

\subsubsection{Combined buffer composition effects}

The final amount of protein adsorbed from all protein solutions falls between $600-800 \mathrm{ng}$ $\mathrm{cm}^{-2}$, suggesting that the final mass of protein adsorbed on silica is only weakly affected by buffer choice. The adsorbed mass corresponds to a protein monolayer and agrees with observations of albumin adsorbed on silica surfaces by QCM-D, ellipsometry, surface plasma resonance and specular neutron reflection $[19,39,45]$.

Since (1) the amount of adsorbed mass is similar in all buffers; (2) the adsorption of proteins is strong, as suggested by minimal desorption on rinsing; and (3) the viscoelasticity of equilibrated adsorbed films are similar in all buffers as suggested by their $\Delta R / \Delta f$ values; we conclude that the properties of the adsorbed film under static conditions are thermodynamically driven. The use of different buffers only impacts on the kinetic process of the film formation but not the thermodynamics of the film formation. If films formed in tribological tests are equilibrated we would not expect to see a large difference in film thickness or film properties due to buffer composition. However, if protein films are removed and replenished during the tests, the protein adsorbed film will not have time to achieve equilibrium. Since the buffer choice affects the viscoelastic properties during the initial adsorption phase of statically adsorbed films, the buffer composition may well affect the viscoelastic property of the protein based tribofilm and the ability of protein films to provide lubrication.

\subsection{Film thickness results}

The film thickness results show that after 20 minutes adsorption, films with a maximum thickness of $3.1 \mathrm{~nm}$ are formed. This is thinner than results obtained from static adsorption measurements with QCM. QCM measurements show that the adsorbed films are not rigid, and can consist of proteins and hydrated ions. Under loading the contact may either compress and denature the protein layers, or force proteins and the associated hydrated ions out of the contact area, resulting in a thinner layer. 
Under rolling two types of behaviour were observed. For Tris Saline pH 8.1 a thin film of around $5 \mathrm{~nm}$ was present throughout the test (Fig. 7.d), which was consistent with a statically adsorbed film. This film was uniform across the contact area as observed using the CCD camera although average film thickness fluctuates slightly over time. For the other protein solutions, the deposited lubricating films are thicker than films adsorbed under static conditions. The deposited films, which can reach an average thickness of $45 \mathrm{~nm}$ fluctuate in thickness over time and across the contact area. The chaotic nature of the measurements was reproducible across tests and was a result of large, irregular deposits on the ball surface as shown in Figure 9. As both saline pH 7.4 and Tris Saline pH 7.4 formed the same deposits but Tris Saline pH 8.1 did not, we conclude that the change in $\mathrm{pH}$ of the buffer disrupts this lubrication mechanism.

The deposited films, which adhered to the surface even when hydrated are consistent with 'Tribofilms' observed both in vivo and in vitro for metal on metal hip joints [8,38,46-49]. Tribofilms have been reported with thickness between $40-100 \mathrm{~nm}$, containing proteins a major constituent, as well as metal oxides. Tribofilms are much thicker than individual proteins and are likely to be composed of protein aggregates [38]. Protein aggregates can form through hydrophobic bonding of exposed hydrophobic regions of the proteins [50]. Under shear, stretching of the protein can expose more hydrophobic groups so that aggregation is more likely to occur [51]. Protein aggregation is also influenced by electrostatic interaction among proteins $[50,52]$. BSA becomes more negatively charged as solution $\mathrm{pH}$ increases. The stronger electrostatic repulsion among proteins in Tris Saline $\mathrm{pH}$ 8.1 solution, as compared to other $\mathrm{pH} 7.4$ protein solutions, can prevent protein aggregation and the formation of thick tribo-film. Proteins in these films could have been denatured due to protein aggregation [38], shear or heat denaturation [46]. Tribofilms may act to reduce friction and wear by reducing adhesion and abrasion of the contact surfaces [46]. The lack of tribofilm deposited at pH 8.1 is consistent with higher wear and friction experienced for protein solutions at this $\mathrm{pH}$ in sliding tests conducted by Fan et al. [37] and Mavaraki and Cann [26].

The results presented suggest that the tribofilm thickness is dominated by protein aggregation, which has been shown previously to occur in the inlet region of the contact [38]. The current study uses a ball-on-flat non-conforming geometry, unlike a hip joint where the contact is highly conformal. As a consequence of the conformal geometry, the inlet region is extended relative to the system implemented in this study, which may increase the chances of protein aggregation. It is possible this leads to restricted inlet fluid flow because of blocking protein deposits and this might impede film formation. However this is speculation and such questions remain for future work.

\subsection{Comparing static and dynamic measurements}

Remembering our original questions, 
1. What is the effect of buffer composition on protein adsorption and EHL film formation?

2. Are static adsorption measurements relevant to the lubrication process?

we have found that for the solutions tested the buffer chemistry makes no significant changes to protein adsorption. lonic strength has a small impact on the rate of adsorption, but not the equilibrium properties of adsorbed protein films. Increasing $\mathrm{pH}$ changes both the kinetics of protein adsorption and the EHL film formation behaviour.

However, whilst $\mathrm{pH}$ is the dominant aspect of the buffer composition in both tests the change in $\mathrm{pH}$ acts in different ways. In the QCM test, a shift in the viscoelastic properties of the protein films during formation was observed between $\mathrm{pH} 5.6$ and 7.4, whilst the adsorption process at $\mathrm{pH} 7.4$ and 8.1 was similar. Under rolling conditions, the change was between $\mathrm{pH} 7.4$ and $\mathrm{pH}$ 8.1, related to the formation of large irregular deposits of aggregated proteins. Our results for Tris Saline $\mathrm{pH} 8.1$ show there may be an adsorbed film on the surface, but any changes in the adsorbed film are masked by the $\mathrm{pH}$ dependent formation of large deposits. Our static QCM adsorption results do not allow us to predict this lubrication mechanism. This highlights the need for direct observation of the proteins (or other synovial fluid species) in a lubricated, contact between artificial joint materials.

\section{Conclusions}

For all buffers tested, adsorption and rearrangement of BSA on the silica surface primarily took place within the first 700 seconds after exposure to the protein solution. The aspect of the buffer which had the dominant effect on static adsorption was $\mathrm{pH}$. Protein layers adsorbed at the lower $\mathrm{pH}$ were initially rigid and relaxed over time to form viscoelastic layers, whilst those adsorbed at higher $\mathrm{pH}$ showed substantial viscoelasticity on initial adsorption. At lower $\mathrm{pH}$, the rate of adsorption was also increased. Film thickness results show that in a rolling contact, thicker protein films were formed than under static conditions in buffers with a $\mathrm{pH} 7.4$ or lower. These thicker films are non-uniform, and compose of thick, irregular protein deposits. At pH 8.1 a uniform film, consistent with the film measured under static conditions is observed. Whilst both static and dynamic measurements show protein film formation is affected by solution $\mathrm{pH}$, the techniques do not highlight the same effects. Static measurements can contribute to our understanding of protein film formation, but do not capture the complexity of protein lubrication mechanisms present in moving synovial joints.

\section{Acknowledgements}

The authors wish to thank the UK EPSRC for funding this research: "In Contact Analysis of Synovial Fluid Lubricating Film Properties" (EP/H020837/1) and Platform Grant "Nanotribology: Measurement and Modelling across the Rubbing Interface" (EP/G026114/1). 


\section{References}

[1] Wang A, Essner A, Schmidig G. The effects of lubricant composition on in vitro wear testing of polymeric acetabular components. Journal of Biomedical Materials Research Part B, Applied Biomaterials 2004;68:45-52.

[2] Kitano T, Ohashi H, Kadoya Y, Kobayashi a, Yutani Y, Yamano Y. Measurements of zeta potentials of particulate biomaterials in protein-rich hyaluronan solution with changes in $\mathrm{pH}$ and protein constituents. Journal of Biomedical Materials Research 1998;42:453-7.

[3] Unsworth A. Tribology of human and artificial joints. Proceedings of the Institution of Mechanical Engineers Part H, Journal of Engineering in Medicine 1991;205:163-72.

[4] Harsha AP, Joyce TJ. Challenges associated with using bovine serum in wear testing orthopaedic biopolymers. Proceedings of the Institution of Mechanical Engineers, Part H: Journal of Engineering in Medicine 2011;225:948-58.

[5] Murakami T, Sawae Y, Nakashima K, Yarimitsu S, Sato T. Micro- and nanoscopic biotribological behaviours in natural synovial joints and artificial joints. Engineering 2007;221:237-45.

[6] Scholes SC, Unsworth A. The Effects of Proteins on the Friction and Lubrication of Artificial Joints. Proceedings of the Institution of Mechanical Engineers, Part $\mathrm{H}$ : Journal of Engineering in Medicine 2006;220:687-93.

[7] Heuberger MP, Widmer MR, Zobeley E, Glockshuber R, Spencer ND. Protein-mediated boundary lubrication in arthroplasty. Molecular Biology 2005;26:1165-73.

[8] Wimmer M, Loos J, Nassutt R, Heitkemper M, Fischer A. The acting wear mechanisms on metal-on-metal hip joint bearings: in vitro results. Wear 2001;250:129-39.

[9] Figueira VBC, Jones JP. Viscoelastic study of the adsorption of bovine serum albumin on gold and its dependence on $\mathrm{pH}$. Journal of Colloid and Interface Science 2008;325:107-13.

[10] Xie Q, Xiang C, Zhang Y, Yuan Y, Liu M, Nie L, et al. In situ monitoring of gold-surface adsorption and acidic denaturation of human serum albumin by an isolationcapacitance-adopted electrochemical quartz crystal impedance system. Analytica Chimica Acta 2002;464:65-77.

[11] Jones KL, O'Melia CR. Protein and humic acid adsorption onto hydrophilic membrane surfaces: effects of $\mathrm{pH}$ and ionic strength. Journal of Membrane Science 2000;165:31-46.

[12] Fang H-W, Hsieh M-C, Huang H-T, Tsai C-Y, Chang M-H. Conformational and adsorptive characteristics of albumin affect interfacial protein boundary lubrication: 
from experimental to molecular dynamics simulation approaches. Colloids and Surfaces B, Biointerfaces 2009;68:171-7.

[13] Koutsoukos PG, Norde W. Effect of the Nature of the Substrate on the Adsorption of Human Plasma Albumin. Colloids and Surfaces 1983;5:93-104.

[14] Widmer MR, Heuberger M, Vörös J, Spencer ND. Influence of polymer surface chemistry on frictional properties under protein-lubrication conditions : implications for hip-implant design. Tribology Letters 2001;10:111-6.

[15] Vörös J. The density and refractive index of adsorbing protein layers. Biophysical Journal 2004;87:553-61.

[16] Serro AP, Degiampietro K, Colaço R, Saramago B. Adsorption of albumin and sodium hyaluronate on UHMWPE: a QCM-D and AFM study. Colloids and Surfaces B, Biointerfaces 2010;78:1-7.

[17] Karuppiah KSK, Sundararajan S, Xu Z-H, Li X. The effect of protein adsorption on the friction behavior of ultra-high molecular weight polyethylene. Tribology Letters 2006;22:181-8.

[18] Murakami T, Nakashima K, Yarimitsu S, Sawae Y, Sakai N. Effectiveness of adsorbed film and gel layer in hydration lubrication as adaptive multimode lubrication mechanism for articular cartilage. Proceedings of the Institution of Mechanical Engineers, Part J: Journal of Engineering Tribology 2011;225:1174-85.

[19] McClellan SJ, Franses El. Adsorption of bovine serum albumin at solid/aqueous interfaces. Colloids and Surfaces A: Physicochemical and Engineering Aspects 2005;260:265-75.

[20] Wang R, Sun S, Bekos EJ, Bright F V. Dynamics surrounding Cys-34 in native, chemically denatured, and silica-adsorbed bovine serum albumin. Analytical Chemistry 1995;67:149-59.

[21] Mavraki A, Cann PM. Lubricating film thickness measurements with bovine serum. Tribology International 2011;44:550-6.

[22] Mazzucco D, Spector M. THE JOHN CHARNLEY AWARD PAPER: The Role of Joint Fluid in the Tribology of Total Joint Arthroplasty. Clinical Orthopaedics and Related Research 2004;429:17-32.

[23] Murakami T, Higaki H, Sawae Y, Ohtsuki N, Moriyama S, Nakanishi Y. Adaptive multimode lubrication in natural synovial joints and artificial joints. Proceedings of the Institution of Mechanical Engineers Part $\mathrm{H}$ Journal of Engineering in Medicine 1998;212:23-35. 
[24] Myant C, Underwood R, Fan J, Cann PM. Lubrication of metal-on-metal hip joints: the effect of protein content and load on film formation and wear. Journal of the Mechanical Behavior of Biomedical Materials 2012;6:30-40.

[25] Mak MM, Jin ZM. Analysis of contact mechanics in ceramic-on-ceramic hip joint replacements. Proceedings of the Institution of Mechanical Engineers, Part H: Journal of Engineering in Medicine 2002;216:231-6.

[26] Mavraki A, Cann P. Friction and lubricant film thickness measurements on simulated synovial fluids. Proceedings of the Institution of Mechanical Engineers, Part J: Journal of Engineering Tribology 2009;223:325-35.

[27] Yao J. The influences of lubricant and material on polymer/ $\mathrm{CoCr}$ sliding friction. Wear $2003 ; 255: 780-4$.

[28] Tadmor R, Chen N, Israelachvili JN. Thin film rheology and lubricity of hyaluronic acid solutions at a normal physiological concentration. Journal of Biomedical Materials Research 2002;61:514-23.

[29] Sauerbrey G. Verwendung von Schwingquarzen zur Wägung dünner Schichten und zur Mikrowägung. Zeitschrift Für Physik 1959;155:202-22.

[30] Kanazawa KK, Gordon JG. Frequency of a quartz microbalance in contact with liquid. Analytical Chemistry 1985;57:1770-1.

[31] Martin SJ, Granstaff VE, Frye GC. a Quartz Crystal Microbalance with Simultaneous Mass and Liquid Loading 1991;2281:2272-81.

[32] Frateur I, Lecoeur J, Zanna S, Olsson C-O a., Landolt D, Marcus P. Adsorption of BSA on passivated chromium studied by a flow-cell EQCM and XPS. Electrochimica Acta 2007;52:7660-9.

[33] Fredriksson C, Kihlman S, Rodahl M, Kasemo B. The Piezoelectric Quartz Crystal Mass and Dissipation Sensor: A Means of Studying Cell Adhesion. Langmuir 1998;14:24851.

[34] Höök F, Vörös J, Rodahl M, Kurrat R, Böni P, Ramsden J., et al. A comparative study of protein adsorption on titanium oxide surfaces using in situ ellipsometry, optical waveguide lightmode spectroscopy, and quartz crystal microbalance/dissipation. Colloids and Surfaces B: Biointerfaces 2002;24:155-70.

[35] Geelhood SJ, Frank CW, Kanazawa K. Transient Quartz Crystal Microbalance Behaviors Compared. Journal of The Electrochemical Society 2002;149:H33.

[36] Stadler H, Mondon M, Ziegler C. Protein adsorption on surfaces: dynamic contactangle (DCA) and quartz-crystal microbalance (QCM) measurements. Analytical and Bioanalytical Chemistry 2003;375:53-61. 
[37] Fan J, Myant C, Underwood R, Cann P. Synovial fluid lubrication of artificial joints: protein film formation and composition. Faraday Discussions 2012;156:69.

[38] Myant C, Cann P. In contact observation of model synovial fluid lubricating mechanisms. Tribology International 2012:1-8.

[39] Wang X, Liu G, Zhang G. Effect of surface wettability on ion-specific protein adsorption. Langmuir 2012;28:14642-53.

[40] Su TJ, Lu JR, Thomas RK, Ox D. The Conformational Structure of Bovine Serum Albumin Layers Adsorbed at the Silica-Water Interface 1998;5647:8100-8.

[41] Heinen M, Zanini F, Roosen-Runge F, Fedunová D, Zhang F, Hennig M, et al. Viscosity and diffusion: crowding and salt effects in protein solutions. Soft Matter 2012;8:1404.

[42] Kao P, Allara DL, Tadigadapa S. Study of Adsorption of Globular Proteins on Hydrophobic Surfaces. IEEE Sensors Journal 2011;11:2723-31.

[43] Barbosa LRS, Ortore MG, Spinozzi F, Mariani P, Bernstorff S, Itri R. The importance of protein-protein interactions on the $\mathrm{pH}$-induced conformational changes of bovine serum albumin: a small-angle X-ray scattering study. Biophysical Journal 2010;98:147-57.

[44] Hiemstra T, De Wit JCM, Van Riemsdijk WH. Multisite Proton Adsorption Modeling at the Solid / Solution Interface of (Hydr) oxides : A New Approach. Journal of Colloid and Interface Science 1989;133:105-16.

[45] Su TJ, Lu JR, Thomas RK, Cui ZF. Effect of pH on the Adsorption of Bovine Serum Albumin at the Silica/Water Interface Studied by Neutron Reflection. The Journal of Physical Chemistry B 1999;103:3727-36.

[46] Wimmer $M$ a., Sprecher $C$, Hauert R, Täger G, Fischer a. Tribochemical reaction on metal-on-metal hip joint bearings. Wear 2003;255:1007-14.

[47] Liao Y, Hoffman E, Wimmer M, Fischer A, Jacobs J, Marks L. CoCrMo metal-on-metal hip replacements. Physical Chemistry Chemical Physics : PCCP 2013;15:746-56.

[48] McKellop H, Park S-H, Chiesa R, Doorn P, Lu B, Normand P, et al. In Vivo Wear of 3 Types of Metal on Metal Hip Prostheses During 2 Decades of Use. Clinical Orthopaedics and Related Research 1996;329:128-40.

[49] Liao Y, Pourzal R, Wimmer MA, Jacobs JJ, Fischer A, Marks LD. Graphitic tribological layers in metal-on-metal hip replacements. Science (New York, NY) 2011;334:168790.

[50] Chan R, Chen V. The effects of electrolyte concentration and $\mathrm{pH}$ on protein aggregation and deposition : critical flux and constant flux membrane filtration 2001;185:177-92. 
[51] Kelly ST, Zydney AL. Mechanisms for BSA fouling during microfiltration. Journal of Membrane Science 1995;107:115-27.

[52] Militello V, Casarino C, Emanuele A, Giostra A, Pullara F, Leone M. Aggregation kinetics of bovine serum albumin studied by FTIR spectroscopy and light scattering. Biophysical Chemistry 2004;107:175-87. 
Figures

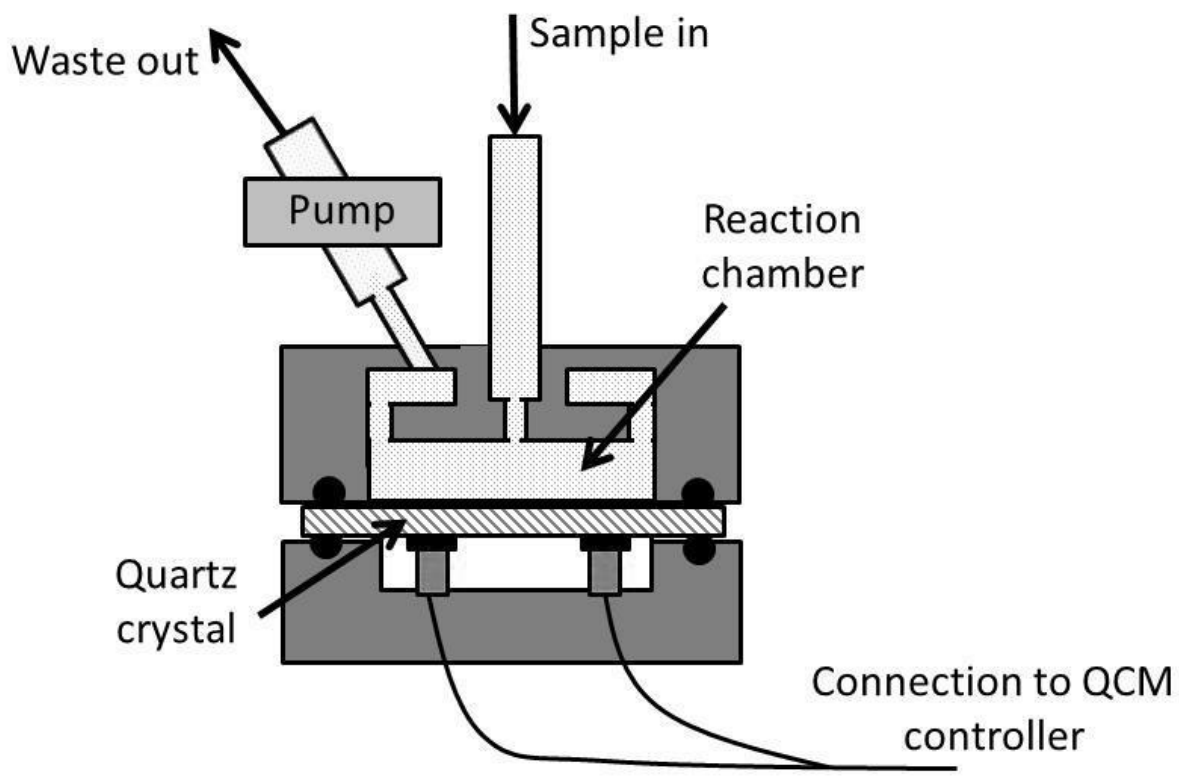

Figure 1 Schematic showing QCM test device used for adsorption measurements with protein solutions under static conditions 


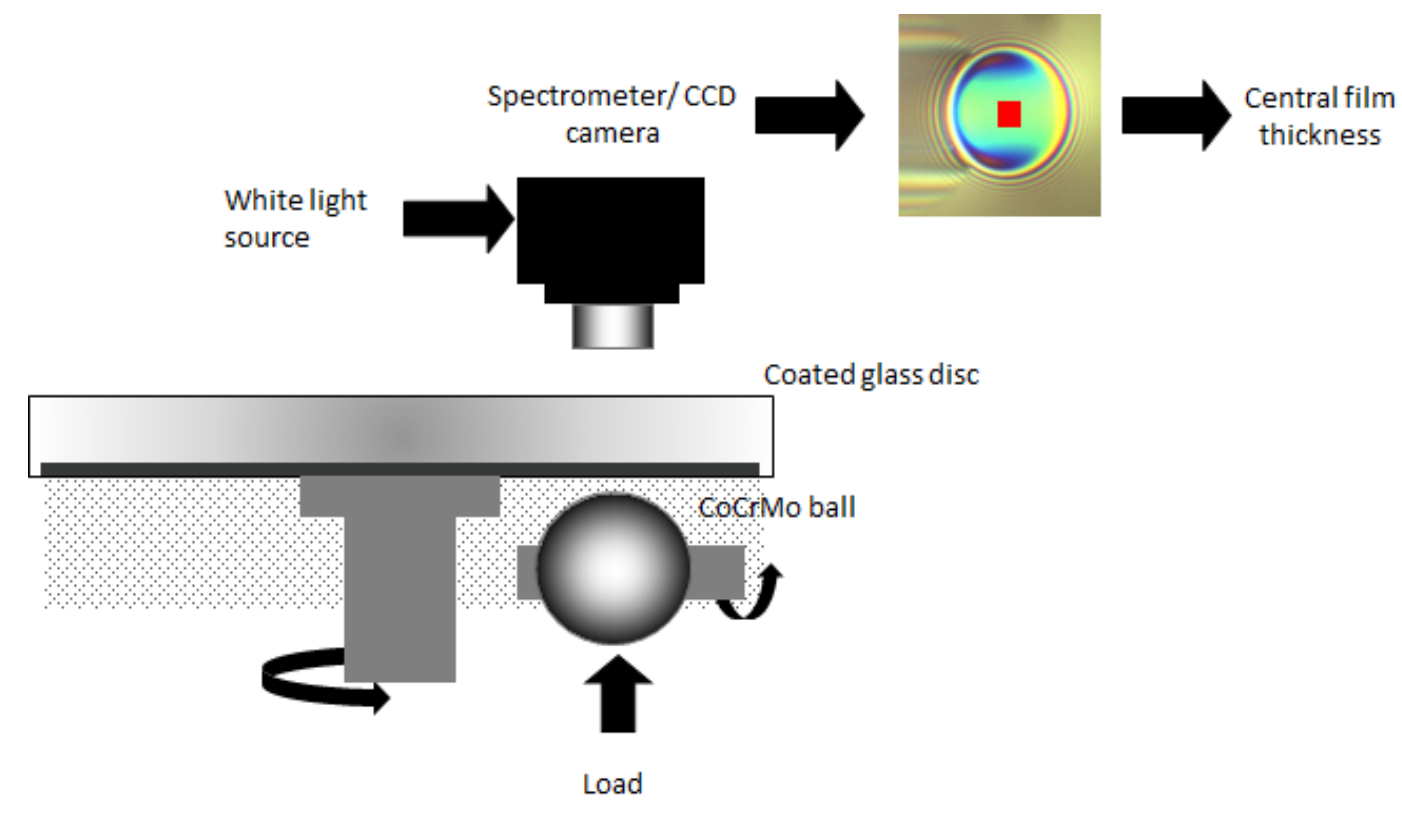

Figure 2 Schematic of the ultra thin film EHL setup which uses an optical interferometry method to make lubricant film thickness measurements 

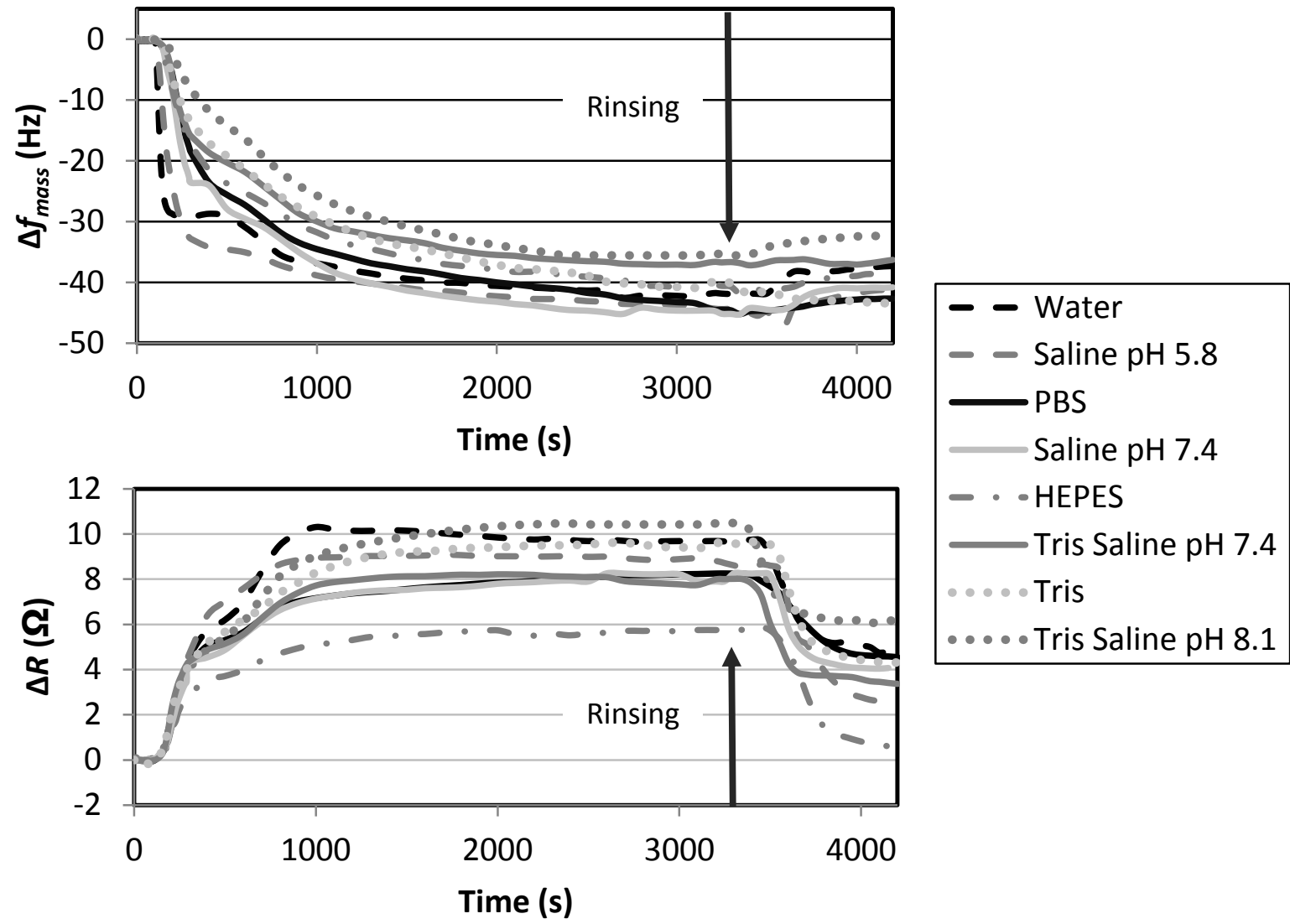

Figure $3 \Delta f_{\text {mass }}$ (top) and $\Delta R$ (bottom) against time for all protein solutions 


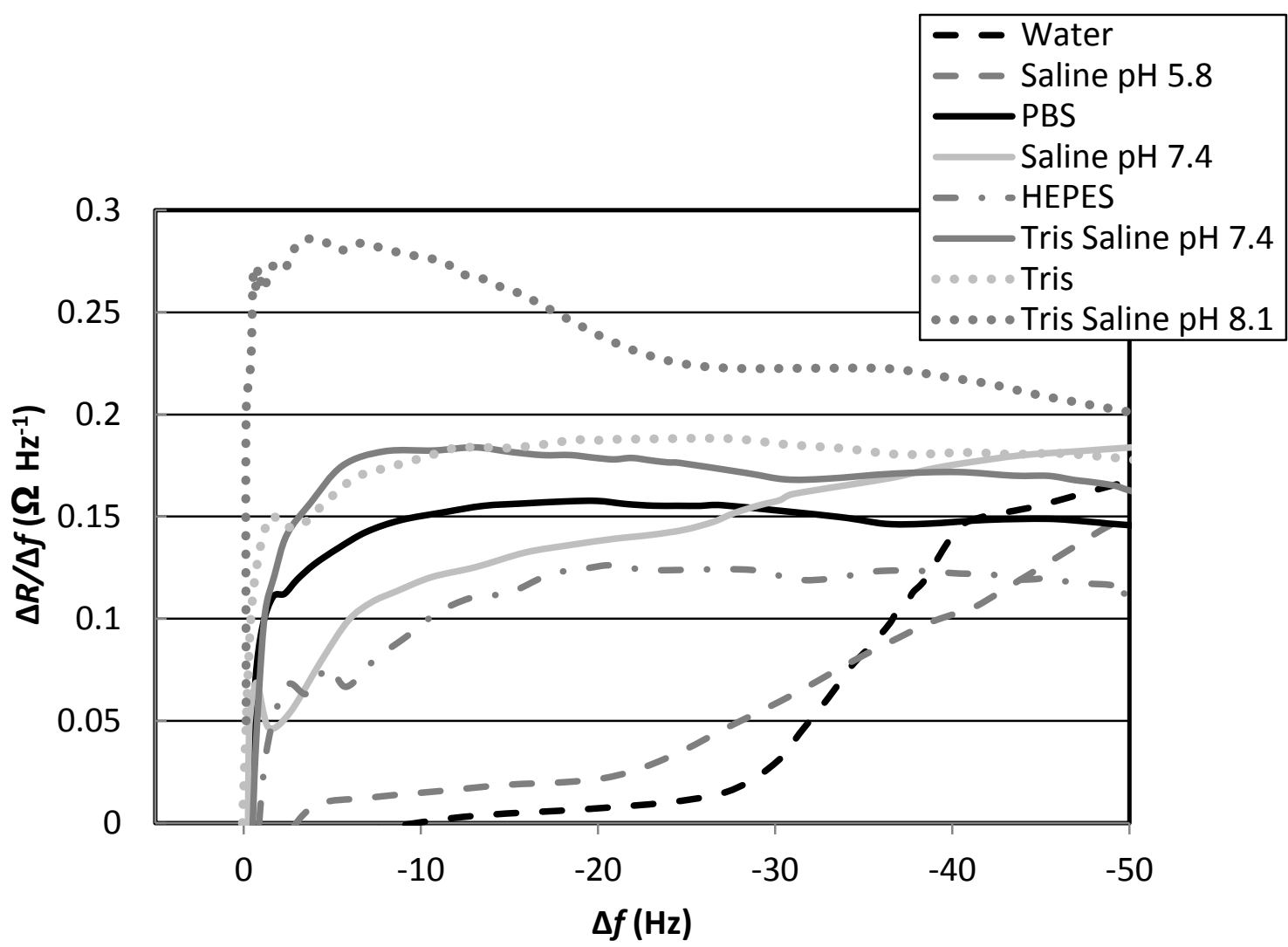

Figure 4 Changes in the ratio $\Delta R / \Delta f$ plotted against changes in frequency for all protein solutions giving an indication of the elastic properties of the adsorbed protein films 


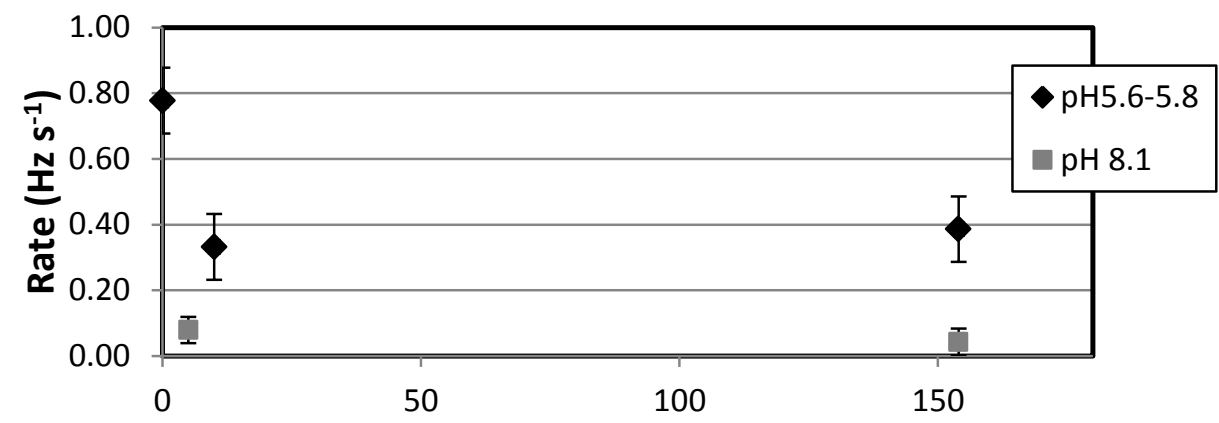

(a) lonic strength (mM)

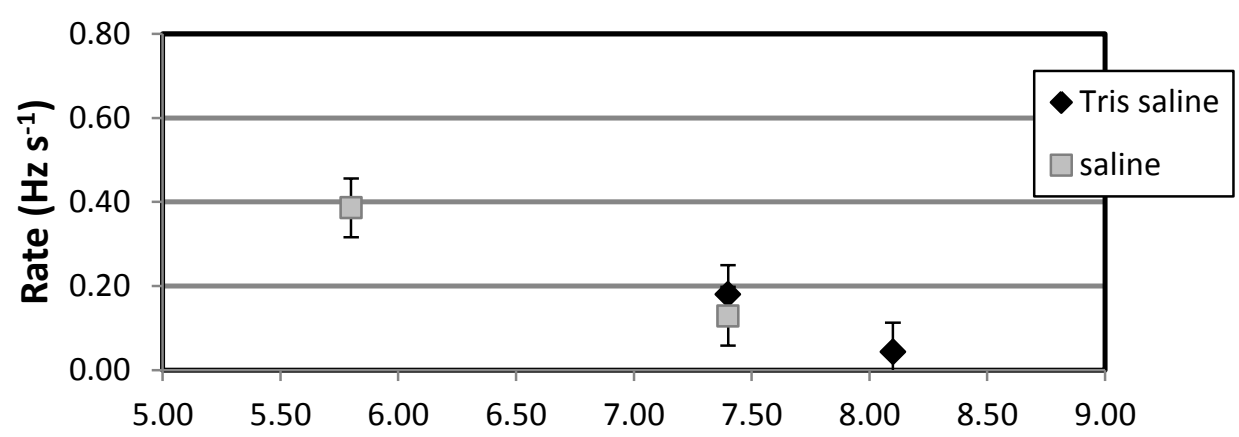

(b) $\mathrm{pH}$

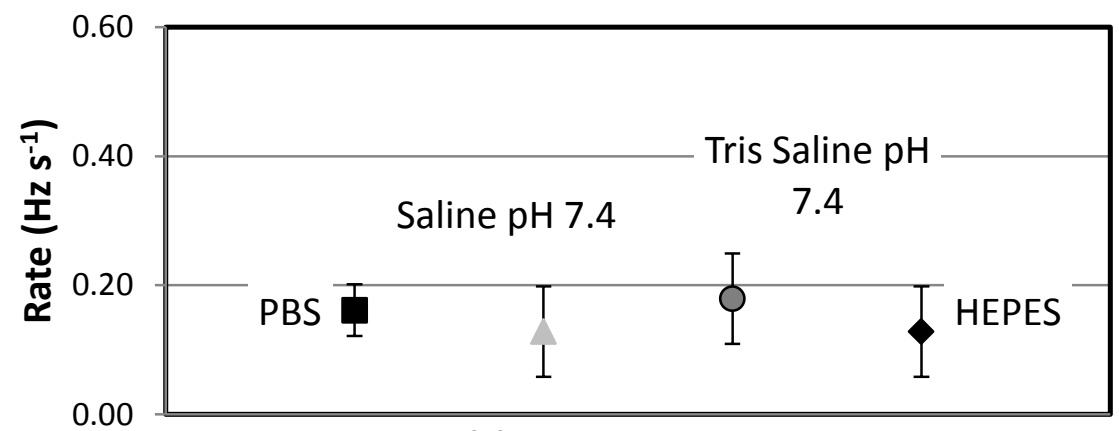

(c) Buffer Chemistry

Figure 5 Initial rate of adsorption as a function of (a) ionic strength, (b) pH and (c) buffer chemistry 


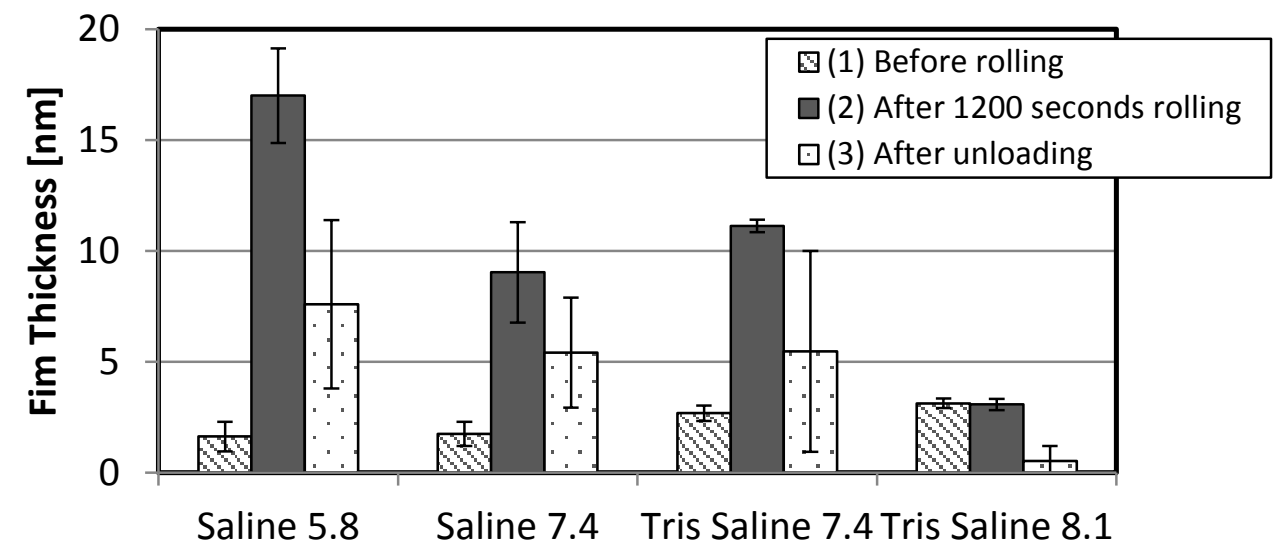

Figure 6 Average film thickness (1) after static adsorption and before rolling, (2) after 1200 seconds rolling and (3) after unloading and reloading 
(a) Saline pH 5.8

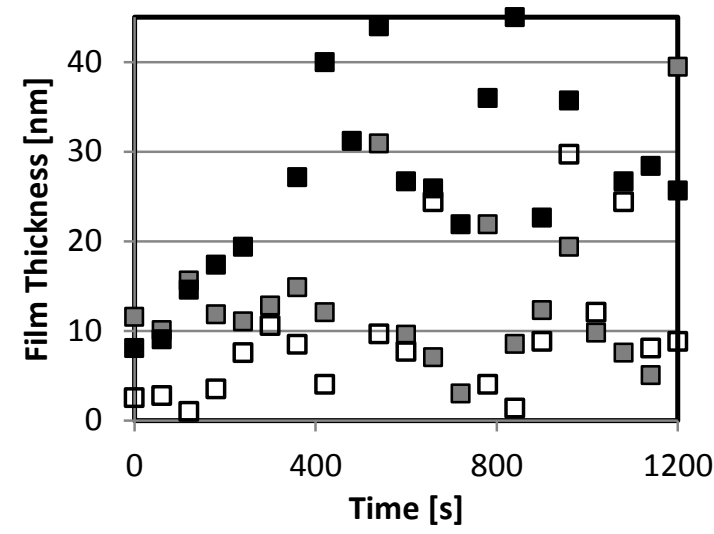

(c) Tris Saline pH 7.4

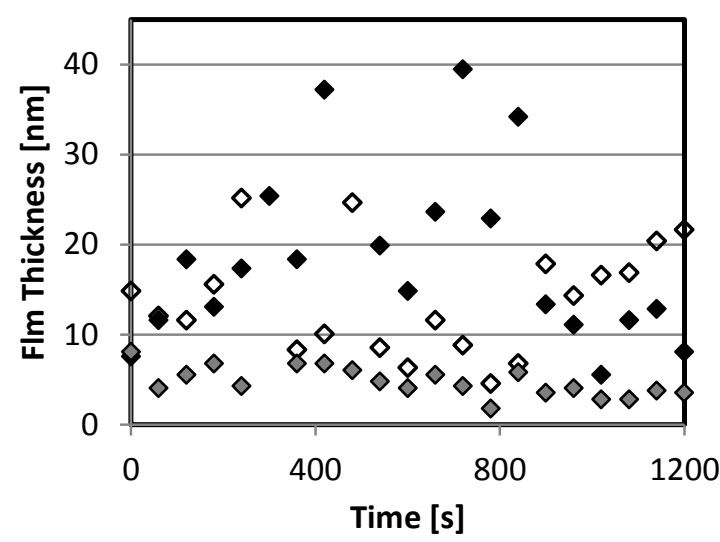

(b) Saline pH 7.4

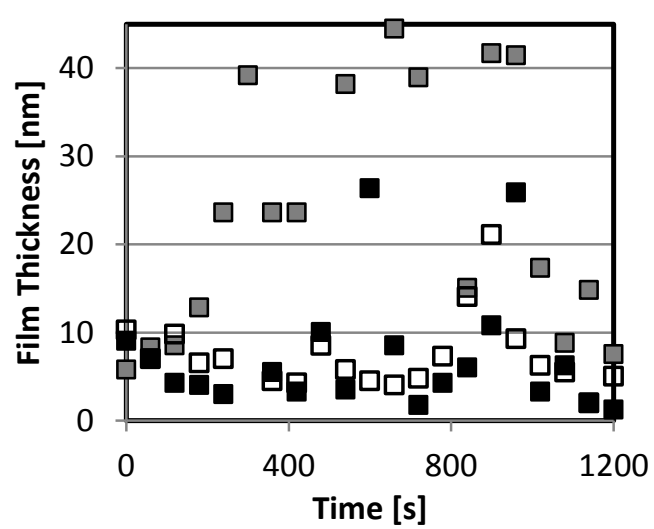

(d) Tris Saline pH 8.1

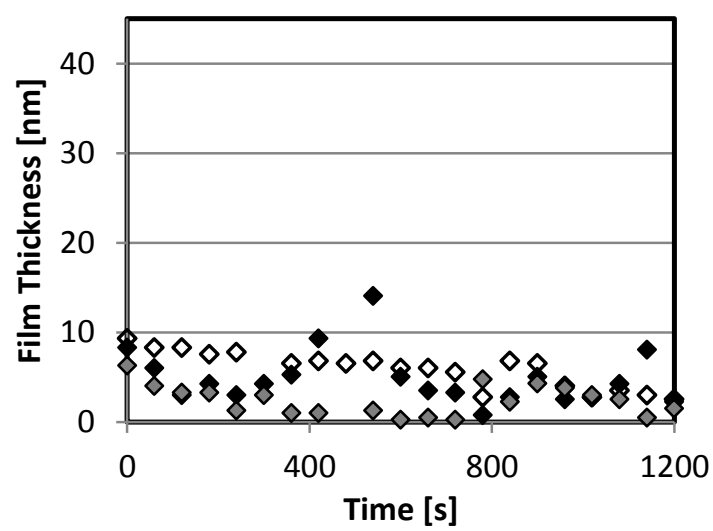

Figure 7 Film thickness results for three tests (different colours) for (a) Saline pH 5.8 (b) Saline pH 7.4 (c) Tris Saline pH 7.4 and (d) Tris Saline $\mathrm{pH} 8.1$ in a rolling contact $(10 \mathrm{~mm} / \mathrm{s})$ 


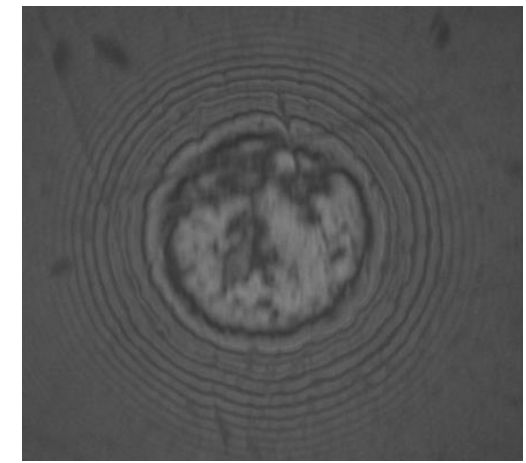

Saline $\mathrm{pH} 7.4$

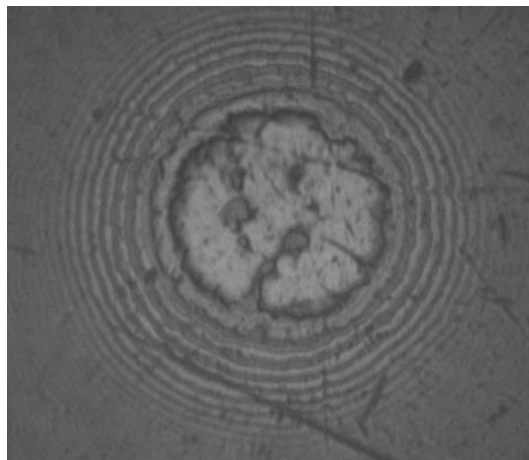

Tris Saline $\mathrm{pH} 7.4$

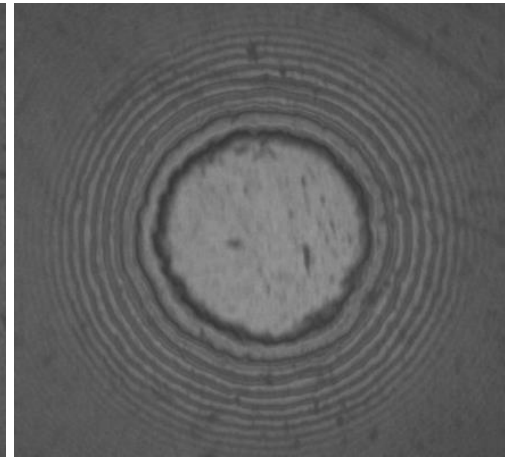

Tris Saline pH 8.1

Figure $\mathbf{8}$ Images from the rolling contact at the end of the test under continued rolling. Saline at pH 7.4 is also representative of Saline pH 5.8 


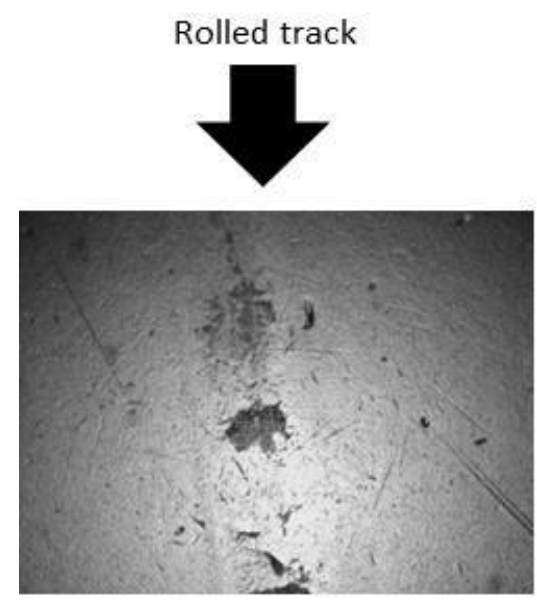

\section{Saline pH 5.8}

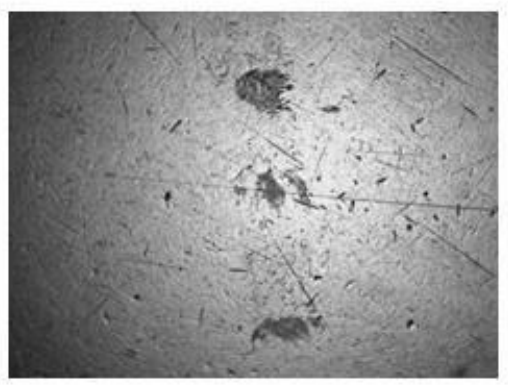

Saline $\mathrm{pH} 7.4$

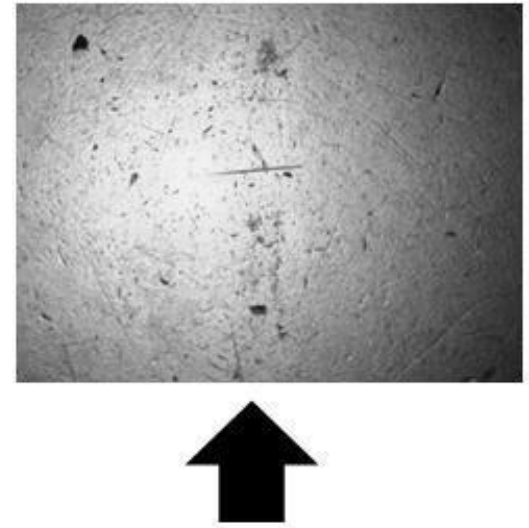

Tris saline $\mathrm{pH} 8.1$

Rolled track

Figure 9 Surface deposits on the ball at the end of the test. Specimens rinsed with water and air dried. 